\title{
The origins of American resource abundance
}

Citation for published version (APA):

David, P. A., \& Wright, G. (1995). The origins of American resource abundance. MERIT, Maastricht Economic Research Institute on Innovation and Technology. MERIT Research Memoranda No. 017 https://doi.org/10.26481/umamer.1995017

Document status and date:

Published: 01/01/1995

DOI:

10.26481/umamer.1995017

Document Version:

Publisher's PDF, also known as Version of record

\section{Please check the document version of this publication:}

- A submitted manuscript is the version of the article upon submission and before peer-review. There can be important differences between the submitted version and the official published version of record.

People interested in the research are advised to contact the author for the final version of the publication, or visit the DOI to the publisher's website.

- The final author version and the galley proof are versions of the publication after peer review.

- The final published version features the final layout of the paper including the volume, issue and page numbers.

Link to publication

\footnotetext{
General rights rights.

- You may freely distribute the URL identifying the publication in the public portal. please follow below link for the End User Agreement:

www.umlib.nl/taverne-license

Take down policy

If you believe that this document breaches copyright please contact us at:

repository@maastrichtuniversity.nl

providing details and we will investigate your claim.
}

Copyright and moral rights for the publications made accessible in the public portal are retained by the authors and/or other copyright owners and it is a condition of accessing publications that users recognise and abide by the legal requirements associated with these

- Users may download and print one copy of any publication from the public portal for the purpose of private study or research.

- You may not further distribute the material or use it for any profit-making activity or commercial gain

If the publication is distributed under the terms of Article $25 \mathrm{fa}$ of the Dutch Copyright Act, indicated by the "Taverne" license above, 


\title{
THE ORIGINS OF AMERICAN RESOURCE ABUNDANCE
}

\author{
by \\ Paul A. David and Gavin Wright \\ All Souls College, Oxford and Stanford University
}

Earlier versions of this article were presented at the meetings of the Economic History Association in Boulder, Colorado, September 27-29, 1991, at the first Russian-American Conference in Economic History, Moscow State University, June 23-25, 1995; and at the IIASA Workshop on "Evolutionary Processes of Growth and Development - History and Theories" in Laxenberg, Austria, 27-29 June 1995. We are pleased to thank Phillip Lim for his extraordinarily able research assistance, and Carol Scott Leonard for stirring our interest in the comparative Russian-American historical aspects of this subject. David gratefully acknowledges the support received from the Center for Economic Policy Research at Stanford, under the auspices of the Technology and Economic Growth (TEG) Program's project on the evolution of university-industry-government R\&D collaborations.

Contact Author: P.A. David, All Souls College, Oxford OX1 4AL, UK

Fax: $44+(0) 1865+279299$; Email: PDavid@vax.ox.ac.uk 


\begin{abstract}
American manufacturing exports became increasingly resourceintensive over the very period, roughly 1880-1920, during which the U.S. ascended to the position of world leadership in manufacturing. This paper challenges the simplistic view that the resource-intensity of manufacturing reflected the country's abundant geological endowment of mineral deposits. Instead, it shows that in the century following 1850 the U.S. exploited its natural resource potentials to a far greater extent than other countries and did so across virtually the entire range of industrial minerals. It argues that "natural resource abundance" was an endogenous. "socially constructed" condition that was not geologically pre-ordained. It examines the complex legal, institutional, technological and organizational adaptations that shaped the U.S. supply-responses to the expanding domestic and international industrial demands for minerals and mineral-products. It suggests that the existence of strong "positive feedbacks"--even in the exploitation of depletable resources--was responsible for the explosive growth of the American minerals economy.
\end{abstract}

Keywords: Natural resources; U.S. industrial leadership; sciencetechnology linkages; mining; petroleum exploration and exploitation; engineering education; positive feedbacks. 


\section{THE ORIGINS OF AMERICAN RESOURCE ABUNDANCE}

By the time of the First World War, the United States had attained world leadership in the production of nearly every one of the major industrial minerals of that era: coal, iron ore, copper, lead, zinc, silver, tungsten, molybdenum, petroleum, arsenic, phosphate, antimony, magnesite, mercury, and salt, with strong second-place status in gold and bauxite. This fact of economic history has not been entirely unappreciated in the past, and yet it has received relatively little direct attention, either in discussions of the country's current economic performance, or in historical accounts of the rise of the American economy to world pre-eminence. Perhaps "primary production" or "extractive industries" are regarded as primitive types of economic activity, which advanced countries move away from as progress unfolds. Yet American manufacturing exports became increasingly resource-intensive over the very period in which the country became the world's manufacturing leader, roughly 1880-1920. ${ }^{1}$ It is arguable, indeed, that resource-intensity and materials-using biases are persistent characteristics of the American economy down to the present day. The full dimensions of American resource abundance, and their implications for the pace and pattern of American economic progress, have yet to be elaborated by economic historians.

This paper asks a different, and perhaps more fundamental question: why did the United States become the world's leading mineral-producing nation? The answer to this question may appear trivially obvious to those approaching the matter from one of the traditional frameworks of economics: Ricardian, neoclassical, or Heckscher-Ohlin models all presume that natural resource production is fundamentally determined by a country's "endowment" of natural resources. Surely resource abundance was a gift of nature, an example of what Parker calls the "sheer luckiness of the American economy."2 When George Otis Smith, director of the United States Geological Survey, wrote in 1919 that "the United States is more richly endowed with mineral wealth than any other country," he expressed the best available scientific knowledge of his day. ${ }^{3}$

Our question may appear to have a transparently simple answer, but this paper reports that "it ain't necessarily so." Minerals with economic value do indeed occur unevenly across the surface of the earth, but between 1850 and 1950, the United States exploited its resource potential to a far greater extent than other countries of the world. The abundance of American natural resources did not derive exclusively from geological endowment, we argue, but reflected the 
intensity of search; technologies of extraction, refining, and utilization; market development and transportation costs; and legal, institutional, and political structures affecting all of these. The situation of natural resource abundance, no less than the condition of so-called technological leadership, is a socially constructed state. Its formation is more appropriately viewed as a process endogenous to the economic and political system, rather than simply a predetermined set of physical endowment constraints imposed exogenously -- by "Nature." To buttress these assertions, we begin with a quantitative demonstration of American "overachievement" in minerals, and then proceed to trace the emergence of this leadership position chronologically. These findings lead us to an account of the main institutional foundations for American mineral resource abundance.

\section{American Minerals in a World Context}

The first two columns of Table 1 present figures on the 1913 U.S. share of the total world production of nine important minerals, and the most recently available estimates of the U.S. share of world reserves. To be sure, the concept of mineral "reserves" suffers from inherent limitations. By their very nature, total potential supplies cannot be known with certainty. Of those that are known, the percentage that are economically recoverable depends upon the price of the commodity and the cost of extraction. These sorts of dividing lines can and do change because of shifts in demand and supply conditions (reflecting physical investments or new technology). The figures in the second column are not very different, however, from those obtained using the alternative concept of "reserve base," which includes resources that are known but marginal or subeconomic. Still, we have no way of assuring that comparison of the 1913 production flows and 1989 stocks is not subject to biases. Despite these qualifications, the present-day estimates provide a useful benchmark, and Table 1 presents a striking picture: for every mineral on the list, U.S. production was disproportionate to what we now believe to be the country's share of world resources. In most cases the gap was huge. Only for coal do the contemporary reserve estimates suggest an obvious geological reason for American domination of world production.

To help clarify the historical issues, one may well ask further questions regarding this evidence. Do the small U.S. shares of world reserves in 1989 mainly reflect the cumulative effects of two centuries of extraction? Or, alternatively, have new discoveries since 1913 mainly occurred in other parts of the world? These questions are addressed in the last two columns of Table 1, which add 1989 estimates of reserves or reserve base to cumulative U.S. production of the mineral in question between 1913 and 1989. They constitute, in other words, the best available 
contemporary estimates of what reserve levels actually were in 1913. It is evident that 1913 U.S. production far exceeded its "endowed" share. To be sure, both accrual and depletion processes were operative, and the balance between them varies from one category of mineral to the next. If all the U.S. gold and lead ever produced could be put back in the ground, the country's relative standing in these industries would be dramatically altered, but total world reserves would only be increased by about twenty percent. In other cases, such as copper or bauxite, the impact of cumulative U.S. production on world reserves would be far less: about six percent for copper, less than one percent for bauxite. Figure 1 illustrates the important example of petroleum, in which the United States dominated world production until the 1960s. Although cumulative U.S. oil production amounts to several times the current level of estimated U.S. reserves, both quantities are small relative to estimates of world reserves (which continue to grow nearly every year). It seems clear that the United States exploited its geological potential well ahead of the rest of the world.

How did U.S. mineral production compare, one may ask, to the country's resource endowments as they were then known to geologists and mining engineers? Global surveys were then in their infancy, but in response to concerns about resource adequacy in Scandinavia and the United States, the XIth International Geological Congress sponsored an ambitious report on Iron Ore Resources of the World in 1910. The Congress commissioned reports from expert observers around the world, asking them to distinguish "actual" from "potential" reserves, and taking note of the degree of investigation entering into the estimates. According to the report, the United States was not only the country most richly endowed with actual iron ore reserves (22.6 percent of the total), but also had the greatest opportunity for future expansion (containing fully 70 percent of the world's estimated potential reserves). In a comparable survey by the United Nations just forty-five years later, the U.S. share of known reserves had fallen to 8.1 percent. By far the most important reason was the discovery and development of vast new reserve centers in Asia, South America, Africa, the Soviet Union, and Australia. Figure 2 depicts the evolution of the estimate of iron ore reserves over time. A similar survey on coal resources by the XII International Geologic Congress in 1913 had an equally striking conclusion about American abundance. That report found that the United States contained more than half of the entire coal supplies in the world. The U.S. is still well endowed with coal, but its estimated share of reserves today is less than one-fourth, indicating that deposits in many parts of the world were simply not known as of 1913.

This evidence suggests that America's exploitation of its mineral potential was far ahead of the rest of the world in the aggregate, but the same conclusion does not necessarily hold in 
comparison with Europe. Table 2 presents similar calculations for the aggregated nations of western and eastern Europe, encompassing an area about half the size of the continental United States (when the Soviet Union is excluded). When these smaller countries are combined in this way, their total production actually exceeded that of United States for coal, bauxite, zinc, iron ore, and lead (though not for petroleum, copper, phosphate and gold). More importantly for our purposes, the figures in Table 2 show that European production in 1913 was even more disproportionate to what is now believed to be that continent's endowment. One might interpret these figures as implying that within the constricted orbit of the "advanced capitalist economy" of the 19th century, the United States really did benefit from an important advantage in mineral endowment. The settlement of America was closely bound up with the natural resource demands of technologies inherited from Europe, identified by such authorities as Wrigley and Thomas as critical to the Industrial Revolution's break with the past. ${ }^{4}$ As rising industrial demands put pressure on limited European resources, the mineral frontier spilled overseas, the United States being among the first to respond.

Even on this reading, however, mineral development in the United States was distinctly unimpressive during the first two-thirds of the nineteenth century. As we recount in the next section, realization of the country's mineral potential came only after large-scale mobilization of human resources and applications of new technologies. Although the US mineral sector certainly did draw upon European skills and investment capital, by the end of the century it had moved well beyond this starting point. In some cases, such as copper, U.S. metallurgical technologies emerged that were far in advance of those in Europe; while in others, such as petroleum, the mineral itself was all but unknown previously, and the adaptation included the development of an entire range of uses for this newly abundant material. Clearly more was involved than mere "endowment."

In our view, the rapidity of American mineral development should be seen both as cause and as consequence of the post-Civil War deployment of human and physical resources to this sector. The high returns to early investments encouraged further investment, resulting not in sharply diminishing returns (as it might have in Europe), but in apparently ever-increasing rates of discovery and production. Our argument is not wholly novel. The suggestion that there was an important "positive feedback" from the exploitation of known geological endowments to the expansion of those endowments was put forward by the compiler of the 1910 report on iron ore:

One of the most striking results of the collection of the reports is that areas covered by the reports of group A [reliable calculations based on actual investigations] contain much greater quantities of 
known and recorded iron ores than is the case with those covered by reports of group B [figures based only on very approximate estimates].

This may be expressed in other words to the effect that the more a district becomes known and its industrial resources are developed, the greater become also its actual iron ore resources. ${ }^{5}$

One could hardly ask for a better description of positive feedback at work.

When we turn our attention to the other continents of the world, the uniqueness of the United States stands out clearly. Table 3 presents comparable figures for the Soviet Union, chiefly Russia, showing a distinct pattern of underachievement relative to modern reserve estimates, except for petroleum. The Russian example is particularly interesting in this context, since the USSR engaged in a crash program of mineral development in the late 1920s and 1930s, achieving a rate of growth in production between 1926 and 1937 more than twice as fast of that of the fastest expansion period for U.S. minerals in the twentieth century, 1902-1917. ${ }^{6}$ This experience, as well as others somewhat less dramatic elsewhere around the world, confirm the essential truth of the compiler's insight. Whether such programs were prudent, or had economic consequences similar to the earlier American case, are of course different questions entirely.

\section{Emergence of the American Minerals Economy: Timing and Causes}

Another set of clues comes from the timing of the explosive emergence of the mineral industries sector of the U.S. economy. From our present vantage point it is difficult to appreciate that so recently as a century ago the view of the United States as a region vastly endowed with valuable natural resources did not strike contemporaries as a hackneyed platitude. Rather, it was something of a novelty, and its assertion was the occasion for expressions of pride in national achievements (for example, Rothwell 1895).

To be sure, the practice of describing the European settlements in North America as exemplifying "land abundance" and its reciprocal condition, "labor scarcity," was of much longer standing. In 1751, Benjamin Franklin observed that Europe was "generally full settled with husbandmen, manufactureres, etc., and therefore cannot now much increase in people;" whereas

"[1]and being ... plenty in America, and so cheap as that a laboring man, that understands husbandry, can in a short time save money enough to purchase a piece of new land sufficient for a plantation, whereon he may subsist a family, such are not afraid to marry...."7 
An abundance of land was recognized to be not quite the same thing as an abundance of natural resources in general, or of mineral resources in particular. Adam Smith echoed Franklin on the stimulus to economic prosperity and population increase provided by "the plenty and cheapness of good land," and at the same time remained decidedly skeptical about the business of mining for precious and semi-precious metals. He judged it to be "the most disadvantageous lottery in the world, or the one in which the gain of those who draw the prizes bears the least proportion to the loss of those who draw the blanks."8 Thus, Smith took pains to point out that while Spain's quest for silver and gold was a motive for colonization that had also animated the New World adventures of other nations of Europe, the latter's expectations of discovering great wealth in American mines turned out to be mostly chimerical:

"It was more than a hundred years after the first settlement of the Brazils, before any silver, gold, or diamond mines were discovered there. In the English, French, Dutch, and Danish colonies, none have ever yet been discovered; at least none that are at present supposed to be worth the working."9

Franklin was thus reiterating a familiar eighteenth century theme -- of the disappointments that awaited Northern European seekers after American mineral treasure -- when he wrote in 1790: "Gold and silver are not the produce of North America, which has no mines."10

The belated emergence of the American mineral economy has not passed entirely un-noticed by historians of the subject. In The Development of Mineral Industry Education in the United States, Thomas Thornton Read remarked:

\footnotetext{
"Although the first colonists in the area that is now the United States, whether Spanish, French or English in nationality, were usually keenly interested in the possibilities of mineral wealth, it is a curious and interesting fact that none of them happened upon the mineral deposits that eventually were to make this the greatest mineral-producing country; up to 1800 it would probably have been rated as rather poor in minerals."11
}

The first real excitement over mineral finds came at the beginning of the 19th century, when large gold nuggets (one weighing $28 \mathrm{lbs}$.) were discovered by white settlers along the eastern border of the Appalachian range, in Virginia and the Carolinas. It was the 1820s that first 
saw the emergence of a wave of activity that might qualify, even vaguely, as a "mining boom." During 1824-1829 the search for gold was resumed and attracted much attention; there was a concurrent rapid development of lead mining in Missouri and on the Upper Mississippi in the Galena district, where Illinois, Iowa, and Wisconsin adjoin one another. Regular shipments of anthracite coal to the Philadelphia market from the Lehigh region of eastern Pennsylvania also commenced in the 1820s, a development that came fully three decades after the discovery of anthracite in that region. More concerted efforts to exploit commercially this novel form of mineral fuel had been stimulated by the high prices of Virginia bituminous coal in Philadelphia during the War of 1812; but success waited upon both the improvement of transport facilities and the dawning understanding that the stuff had practical uses other than as a paving material, and would indeed release a lot of thermal energy if burned in a grate. ${ }^{12}$

Quantitatively speaking, the country's position of leadership in mineral production was a post-Civil War development, albeit one for which many of the behavioral elements were observable earlier. Harvey and Press note that prior to 1870, Britain was self-sufficient in iron ore, copper, lead, and tin, and "Britain was easily the most important mining nation in the world."13 U.S. lead mine production, for example, did not surpass that of Britain until the late 1870s (Figure 3). Leadership in coal came even later. Despite a vastly larger area, U.S. coal production did not pass Germany's until 1880, and Britain's only in 1900 (Figure 4). Leadership or near-leadership in copper, iron ore, antimony, magnesite, mercury, nickel, silver, and zinc all occurred during the period between 1870 and 1910. ${ }^{14}$ Surely this correspondence in timing among so many different minerals cannot have been merely coincidental. ${ }^{15}$

One might be tempted to explain the apparent coincidence very simply, on the view that the rise of mineral production was essentially a reflection of the territorial expansion of the nation. How could the mineral deposits of Colorado, South Dakota, and Montana have been discovered and developed until these regions had been brought within the borders of the nation and settlement begun? But the phenomena under discussion cannot be explained away in this manner. For one thing, some of the most dramatic production growth did not occur in the far west, but in the older parts of the nation. Copper in Michigan, coal in Pennsylvania and Illinois, oil in Pennsylvania and later Indiana, are all examples. The California gold rush was only the largest and most spectacular of a series of mineral discoveries and "rushes" that occurred in almost all parts of the country and accelerated across the nineteenth century. ${ }^{16}$

Nonetheless the opening of the vast western public domain to minerals exploration was undeniably a major part of the story. This association merely underscores our main point, that Americans were looking to the land for very different purposes than were the Mexicans or the 
European powers contending for the Oregon territory. Mineral discoveries were not mere byproducts of an inexorable settlement process. They were instead the results of purposeful exploration, and often occurred in areas that were (and in many cases, still are) remote from population centers. Exploiting these resources required extensive investment in transportation and other forms of infrastructure, and in many cases major new technologies of extraction and processing as well. American mineral development stands in marked contrast to the case of nineteenth-century Russia, whose failure to develop its vast reserves of coal and iron ore is attributed to the inconvenient location of major deposits thousands of miles from population centers, as well as to unevenness of ore quality, high transportation cost, and the lateness of discoveries. ${ }^{17}$ Every one of these "handicaps" could as easily be ascribed to nineteenth-century America, yet they did not stop the country's rise to world mineral leadership.

The example of copper further illustrates our view that the American experience was unique, in comparison with other well-endowed parts of the world. Figure 5 shows that Chilean copper production exceeded that of the US until 1880, and nearly recovered its supremacy again in the 1930s. In between, however, during the 1880-1930 era of US minerals ascendancy, there was no comparison. The US performance represented far more than discovery, but a revolution in copper metallurgy as well, including such new processes as bessemerizing, pyritic smelting, and electrolytic refining, that allowed the exploitation of low-grade "porphyry" coppers. Together, these advanced techniques allowed US firms to take advantage of the empirical regularity known as "Lasky's Law," an inverse relationship between the grade of the ore and the size of the deposit. The huge fixed costs entailed in such projects led the copper industry into increasing dominance by a handful of giant firms. The US led the world both in the size of its copper firms and in the development of the new technologies. ${ }^{18}$ Clearly the intuition is mistaken that places "resource-based" development necessarily at the "low-technology" end of a spectrum of alternatives.

\section{Private Incentives: The American Law of Mining}

A logical place to begin in interpreting the unique performance of the U.S. mineral economy is with the incentive structure, the rules of access and the character of the property rights that determined the balance between effort and expected reward. Both admirers and critics of U.S. mining have agreed that nineteenth-century U.S. mineral law was unique, in that the government claimed no ultimate legal title to the nation's minerals, not even on the public domain. ${ }^{19}$ The United States maintained the principle of open access for prospecting; indeed the 
very term "prospector" is an Americanism dating from the 1850s, referring to a social type said to be unique to this country. ${ }^{20}$ All other major mining systems reflected the lasting influence of the ancient tradition by which minerals were regarded as the personal property of the lord or ruler, who granted user rights as concessions if he so chose.

If the legal regime for U.S. mineral development was uniquely liberal, this status may not have descended from deep philosophical or constitutional principles set down by the founders. The Land Ordinance of 1785 did indeed claim for the federal government "one third part of all gold, silver, lead and copper mines" on the public domain, and in the early nineteenth century, the federal government asserted these property rights forcefully, trying during one important phase to regulate mining activity closely for revenue purposes. Between 1807 and 1846, the government managed a leasing system for lead mines, first in Missouri, then in the Galena district of Illinois, Iowa, and Wisconsin. ${ }^{21}$ During the 1820s and 1830s, the "Galena Experiment" seems to have functioned fairly smoothly: miners obtained exclusive permits to work a given area, and were required to bring their ore to one of the officially licensed smelters, from whom the government collected a ten percent royalty. Between 1825 and 1829, production grew rapidly, and federal revenues were enhanced. The system fell apart in the 1830s, however, because of noncompliance on all sides: by the miners, who evaded the licensed smelters; by the smelters, who refused to pay the royalties; and by federal agents, who fraudulently sold mineral land at minimum prices as farmland, often for their own personal benefit. An estimated three-fourths of mineral lands passed into private hands in this way. ${ }^{22}$ Attempts to revive the leasing system for Michigan copper lands in the 1840s were no more successful, and leasing was repealed in 1846.

The liberal character of federal policy, it seems, derived less from philosophical principles than from lack of enforcement powers. This weakness was underscored all the more in 1848 when gold was discovered 3000 miles away, on the American River near Sacramento, California. Thus it was that the great California gold boom occurred under a virtually complete absence of governmental authority, and technically constituted trespassing. ${ }^{23}$ The principle of open access for exploration on the public domain was simply a de facto reality. In these chaotic conditions, "miners' meetings" in local camps or districts drew up simple rules for recording, enforcing, working and transferring claims, in an effort to preserve order and minimize violent disputes. Many of the elements of the mining camp rules ultimately became codified in the federal Mining Laws of 1866 and 1872: open access for exploration; exclusive rights to mine a specific site upon proof of discovery; limits on the size of individual claims; and the requirement that a claim be worked at a certain frequency or else be subject to forfeit. Since the publication of Charles Shinn's 
Mining Camps: A Study in American Frontier Government in 1885, these codes have been celebrated by historians as examples of fraternal cooperation among rugged individualists, and by economists as illustrations of the endogenous rise of secure property rights in the absence of effective governmental authority. ${ }^{24}$ This perspective deserves close scrutiny.

If it were indeed true that stable, simple rule structures grew up from the consensi of early mining camps, there would be little reason to expect that such codes would provide efficient incentives for future output growth over any lengthy span of time. Any agreed-upon rules might be better than violent warfare, but the earliest miners to arrive would have every reason to operate in their own joint interest relative to potential newcomers, especially on such issues as the maximum size of individual claims, and the number of days per week that a claim must be worked. Indeed, McCurdy reports that political settlements within mining camps were regularly disrupted by inflows of outsiders, who mustered new majorities to alter regulations in favor of freer and more equitable access to the choicest sites. ${ }^{25}$ Perhaps partly because the local rules did change frequently, allegations of claim-jumping were common, and the resulting disputes "inundated the courts with actions for ejectment." It is true that the California legislature, unable to agree on policies of its own, gave legal authority to local codes "when not in conflict with the constitution and laws of this state." But the state courts did not simply adopt and give the force of law to every local camp code. Instead, using broad discretionary judicial powers in the absence of specific legislative direction, the courts tried carefully to balance the rights of established miners against the desirability of continuing access for new arrivals, freely invoking such slippery notions as "reasonable use" and "public purpose," giving some weight but not ultimate authority to "customary" local codes. As Stephen J Field wrote for the California Supreme Court in 1860: "The whole doctrine of possession must be controlled and modified by the peculiar nature of the subject and by surrounding circumstances." 26

A more basic shortcoming of the property rights literature on this subject is that it is primarily addressed to questions of static efficiency in resource allocation, when the major historical issues have to do with the economic incentives to engage in costly search activity under conditions of high uncertainty and doubtful appropriability. It is far from clear that rules to safeguard fair and efficient resource use ex post (i.e., after a discovery has been made) will also function successfully as incentives for search, ex ante. For example, the limitation on the size of individual claims, which was a feature of virtually all of the early codes, though entirely reasonable in the context of a functioning mining camp, surely diminishes the expected payoff to a major discovery in a new location. Much of the work on property rights begs this question, by taking the major discoveries as exogenous, and tracing the consequences for property rights 
in the newly-invigorated industry in question. ${ }^{27}$ Although the timing of any particular discovery will of course be subject to elements of chance, and hence might be considered exogenous with respect to the economic variables in a given geographic setting, in the aggregate this approach takes as exogenous the very success in mineral development that we have set ourselves to explain!

An earlier writer did advance a logical and intelligent argument linking mineral supremacy to the American law of mining. Writing in 1918, the Colorado mining authority Theodore Van Wagenen argued that the country's unique performance was attributable to two basic principles of the law: (1) "free prospecting privileges, coupled with simple and inexpensive rules for the initiation of titles..." and (2) "the extralateral right of pursuit for all forms of mineral deposits that possess continuity in length and depth..." The latter principle was said to be of particular importance in encouraging those forms of mining that required heavy fixed capital investment, by allowing the investor to capture the full value of a vein of ore, wherever it might lead. Van Wagenen concluded: "This is the magnet that first attracted the prospector, and which has ever since held his interest and retained his services. No mining district in the world has ever been so thoroughly explored as that of the western United States, nor does any begin to compare with it in results obtained..."28 This interpretation has the ring of plausibility and the charm of simplicity. But it is misleading in essential respects.

In the first place, much of the progress of the minerals economy was not in fact carried under the auspices of the federal mining laws, but through evasion of these laws. Coal lands, for example, were explicitly exempted from the Mining Laws of 1866 and 1872. An act of 1864 authorized sales of coal land by auction, but no land was ever auctioned under this act. An act of 1873 authorized the sale of coal land by claim and patent; but of the estimated 6 million acres of coal land transferred into private hands between 1873 and 1906, only 7 percent used this system. ${ }^{29}$ Most of the coal land was dispensed as farmland, or under some other laws. The same was true of the iron lands in the Lake Superior district. The states of Minnesota and Wisconsin were exempted from the Mining Laws, and the bulk of the area was fraudulently privatized under the provision of the Homestead Act. ${ }^{30}$

Second, as Van Wagenen's own world survey reveals, it would be difficult to maintain that either of these principles were truly unique to the United States. Free prospecting also prevailed in western Canada, Mexico, and most of South America; elsewhere, requiring a modest fee for a prospecting license (such as the "miner's right" purchasable for $£ 1$ in Australia) could hardly have been decisive. Sumner La Croix points out that the legal rules adopted in Victoria and New South Wales at the time of the Australian gold rush, though initially driven by the 
colonial governments' desire to control settlement and raise revenue, in short order developed along lines similar in their basic structure to those in the United States. ${ }^{31}$ Indeed, a careful comparative study of American and Australian mining law published in 1910 found much to be said in favor of the latter, both in terms of maintaining incentives and minimizing wasteful disputation and respect for the law: "The discovery doctrine has been responsible for more essentially false declarations than probably any other enactment on the American statute books. The extralateral right doctrine has resulted in an endless amount of litigation, involving the absolutely unproductive expenditure of millions..."32

The principle of extralateral rights had ancient origins; it was elaborated in Agricola's famous essay on mining (translated by Herbert Lou Henry Hoover). With minor variations, it was observed in Germany, Britain, and Spain as well. If it was not adopted universally, the reason may well be that the doctrine was by no means as clearcut in practice as it may sound in principle. Where lode-veins were distinct and continuous, it may be appropriate to allow the first discoverer to pursue a vein once started, even under another person's surface land. But where mineral deposits were of a different character, where veins were fractured or discontinuous, with branches on various levels and outcroppings at numerous locations, rival extralateral rights could be the subject of endless litigation. The most numerous and expensive cases involved the "apex law" in copper mining, the principle that a vein belonged to the owner of its origin, or apex. The celebrated figure of Frederick Augustus Heinze, a mining engineer who did not "relish drudgery," made a fortune through strategic purchase of apex claims in Montana, putting him in position to hold up giant copper companies for payment. Many mining experts urged repeal, calling it "an absurd law" that had created "a chaos of confusion." But apex litigation was ultimately circumvented, not by progress in the law but by widespread consolidation of mining property, with agreements on vertical boundaries between adjoining owners -- a private adoption of a "foreign" legal doctrine. ${ }^{33}$

In the case of petroleum, the breathtaking rise of the industry occurred under the aegis of a manifestly inadequate legal precept known as the "rule of capture." Analogous to the apex rule for hard-rock minerals, the doctrine held that a well owner had legal title to any oil drawn from the ground onto his property, regardless of the original source or location of the oil. The result was a classic illustration of common-pool resource problems, generating huge inefficiencies in the form of excessive drilling costs, and saddling the industry with extremes of instability in production and prices, as drillers raced to be the first to pump from any newly-discovered pool. Yet the system resisted reform down to the 1930s. As Gary Libecap and his co-authors demonstrate, the logical appeal of unitization in the oil fields was thwarted by chronic disputes 
over the value of leases, and by distributional issues persistently pressed by a powerful lobby of independent oil men. ${ }^{34}$ Can one reasonably argue that the development of the American oil industry represents a response to secure property rights and the rule of an evolving, ever-moreprecisely defined body of law? The system did indeed encourage maximum rate of extraction from an oil field once discovered; but if it had also resulted in the cessation of all oil exploration, economists would have no difficulty rationalizing this outcome.

None of this discussion is intended to reject the simple assertion that the U.S. rise to world mineral leadership was facilitated by an accommodating legal environment. We merely mean to argue that laws did not function as an exogenously defined incentive system, but as flexible and tolerant instruments, responsive to the changing demands of the minerals industries. State courts and legislatures did not merely define legal rules to encourage the release of private entrepreneurial energies. Instead, they actively encouraged development, by such measures as tax exemption for mine shafts and buildings, low taxes on mining income, statutes of limitations on claims disputes, and even the use of eminent domain rights on behalf of private mining companies to help guarantee access to underground mines. ${ }^{35}$ As the rise of mineral production came to rely increasingly on large corporate organizations using sophisticated technologies, federal and state authorities accommodated by waiving the early mining-camp limits on the number of claims that an individual or corporation could file. The fee for patenting such claims was fixed at a nominal level in 1872 (\$2.50 to \$5.00), and remained unchanged thereafter. Behind these measures lay a broad local, state and federal consensus on the desirability of mineral development, and an emerging set of networks operating increasingly at the national level in support of this goal.

\section{Geological Surveys and Public Knowledge Infrastructure}

Provision of geological information was perhaps the most important initial step in the collective enterprise of resource discovery and exploitation. Recognition of the private economic value of such information drew geologists at an early stage directly into lucrative employments in the business of exploring for mineral wealth. According to Robert Bruce, geologists were the most conspicuous among those antebellum scientists (about 14 percent of the total) listed in the Dictionary of American Biography who drew their livelihoods chiefly from private industry rather than educational and government employments. ${ }^{36}$ The popular perception that they had a "map to the buried treasure" helped to form and maintain a business constituency to whose interests scientists engaged in the study of geology, paleontology, and topography were able to 
appeal repeatedly, and successfully, when seeking governmental patronage for their endeavors to augment the stock of scientific knowledge. The resulting body of geographic and geological information formed a critical part of the public knowledge infrastructure that supported the exploration and development activities of the U.S. minerals industry.

From the very first state survey, authorized in North Carolina in 1823 during the mounting excitement over gold finds in the region, the funding of state geological surveys was the leading form of direct aid that state governments provided for science in the antebellum era. More than half of George P. Merrill's massive study, The First One Hundred Years of American Geology (1824) is devoted to "The Era of State Surveys," 1830-1880. The establishment of a State Geological Survey in Massachusetts in 1830 was followed closely by similar undertakings in fourteen other states during the 1830s. By 1860 twenty-nine of the thirty-three states had sponsored surveys at one time or another. The states supported not only the field work of geologists, but also the publication of their sometimes voluminous findings. ${ }^{37}$

The discoveries in the Michigan copper region provide a striking early instance of the role of these surveys and geologists' involvement in exploration and mineral resource exploitation. In 1840, the first scientific exploration of the Keweenaw peninsula was undertaken by Douglass Houghton, first geologist of the new state. Houghton's report, indicating the presence of fabulous copper deposits there, led Congress to appropriate funds for the purchase of lands from the Chippewa Indians in 1841. During the ensuing rush of individual prospectors and mining companies, a federal geological survey was begun under the direction of Charles T. Jackson, a leading geologist and chemist in Boston. Completion of this survey in 1850 provided the first geological maps of the district adequate to support rational exploration and development work. The Michigan copper deposits were the first major U.S. field to be developed, and also launched a number of noteworthy scientific careers. Josiah Whitney, a young protege of Jackson's who had been sent off to Europe to pursue interests in chemistry, returned in the summer of 1845 to work in the Copper Country as a geologist for a mining company. Forsaking chemistry, Whitney soon joined the staff of Jackson's survey in 1847, and within a few years had established himself as a leading industrial consultant: "Making five hundred dollars a month, he remarked in 1853, he could not afford to be a Yale professor." ${ }^{138}$ His reputation was further enhanced by his publication the following year of The Metallic Wealth of the United States, the first comprehensive work on American ore deposits, a book that became widely known, and helped to gain him a position as director of a state survey for California in 1860.

Despite Whitney's remark about relative salaries, university professors of that era could sometimes be entrepreneurial indeed while on the job. An early example was the career of J.P. 
Lesley, who graduated from the University of Pennsylvania in 1838, and then worked on the first state geological survey. After a decade in the ministry, he published A Manual of Coal and Its Topography in 1856, and in the same year became secretary of the American Iron Association. He also worked as a private consultant, and in 1857 his office stationery carried the following letterhead: "Geology and Topography. Geological and other Maps constructed; Surveys of Coal Lands made; Mineral Deposits examined; Geological Opinions given to guide purchasers, and Reports made to Owners and Agents. Orders for elaborate Topographical Surveys from Rail-road and other companies, will be executed in scientific principles, and in the highest style of the art." Two years later he joined the faculty of the University of Pennsylvania, was made dean of the science department in 1872, and dean of the new Towne Scientific School in 1875. He was librarian, secretary, and vice-president of the American Philosophical Society, and a charter member of the National Academy of Sciences. During all this time he continued his consulting activities, traveling in 1863 to Europe for the Pennsylvania Railroad to study the Bessemer steel process. He also served as state geologist, directed the second Pennsylvania geological survey, and for four years edited a weekly newspaper, United States Railroad and Mining Register. ${ }^{39}$

With the opening of the trans-Mississippi west after the Civil War, there was a commensurate expansion of the scale of resources committed to geological surveys. The federal government already had some relevant experience. Two generations of army officers and engineers had established a tradition in which topography was valued as the highest form of peacetime knowledge, and civilian scientists were often invited to join the western expeditions of the Corps of Topographical Engineers. ${ }^{40}$ Thus it was natural that in 1867 Clarence King, a civilian alumnus of the Sheffield Scientific School at Yale and of the Whitney survey in California, would approach the Corps of Engineers with his proposal that the War Department allocate funds for the Geological Exploration of the Fortieth Parallel. Congressional authorization was swift, and the survey (along the route of the Pacific railroad) got underway the same year.

The first publication from this investigation was out by 1870. The work, Mining Industry, added substantially to the geological knowledge of the district's gold and silver deposits, and contemporaries saw particular value in its chapters on methods and equipment for digging and treating the ores at Comstock. In 1872, King displayed his shrewd sense for mobilizing industrial support for scientific enterprises when he and his field team discovered and exposed a fraudulent mining scheme, involving the seeding of secret grounds with uncut diamonds, which had completely fooled one of the ablest mining engineers of the day. The San Francisco Bulletin, after lauding King for having done the public "a memorable service," went on to acclaim 
"the practical value, in the ordinary business of society, of scientific education and research.... These public surveys 'pay' in more senses than one, and even those who care nothing for wider and fuller knowledge for its own sake, must hereafter admit that Government expends no money more wisely and usefully."41

This triumph had direct private benefits for King as well. He was besieged by offers to examine property, and according to a friend, "he never charges less than $\$ 5000$ to look at a mine."42

The most enduring significance of the Exploration of the Fortieth Parallel was institutional, for it exemplified a conception of government science that combined economic geology and technology; that idea carried over in the founding of the U.S. Geological Survey in 1879, and its development under its first director -- Clarence King. The Geological Survey emerged as the leading scientific bureau of the post-Civil War era and was the most productive governmental research agency of the nineteenth century. It enjoyed the advantages of a dual organization, "wielding the power of the government bureau while enjoying the freedom of the scientific society," which it used to make geology and paleontology the leading research sciences in America. The payoff to the early topographical and metallurgical work of the USGS in western mining centers had a lasting impact on the popular appreciation of the practical benefits of scientific research. ${ }^{43}$ It was left to King's astute successor, J.W. Powell, to extend the work of the bureau east of the Missippi, and finally to secure (in 1882) congressional appropriations to begin the preparation of a geological map of the entire United States, not simply the public domain. Although private professional work while on the staff was not permitted, the survey acquired a reputation as an ideal steppingstone toward success in the mining sector. ${ }^{44}$

The development of the petroleum industry exhibits many of the elements that were essential to rapid exploitation of mineral deposits in the United States, as well as the evolving institutional relationships among government agencies, academic institutions, and corporations. In the initiation of this industry, the role of applied science was negligible. T. T. Read writes:

The boring of deep wells for brine and water was so old a technique that books had been published on the subject in Europe, while for nearly 2000 years the Chinese had practiced it without writing much about it. When the first well in this country specifically intended to produce petroleum. . was put down at Titusville in 1859, it was bored by an experienced brine-well driller, "Colonel" Billy Smith, and involved nothing novel except the idea that crude petroleum 
would come out of it instead of brine.

He adds that the problem of where to drill the wells was solved, in the beginning, "by putting down the first one near where petroleum came to the surface, and moving outward till the boundaries of the pool had been passed." ${ }^{45}$

As petroleum discoveries moved onto more difficult terrain, drilling was facilitated by technological improvements, such as the replacement of the cable drill by the rotary drill. Already used with considerable success in drilling for water, the rotary drill was first applied to petroleum production around the turn of the century, including the Spindletop gusher of $1901{ }^{46}$ In addition to technological changes, the application of petroleum geology played a critical role in the development of the industry. The increasing use of petroleum as a source of energy, and the expanding range of petroleum by-products with diverse market potential, provided the "demand push" for the systematic deployment of scientific knowledge. As early as 1860-61, Lesley included petroleum in his treatment of economic geology at the University of Pennsylvania. At Columbia's School of Mines, Francis L. Vinton's instruction in mining discussed the drilling of artesian, brine, and oil wells, while Charles F. Chandler, its dean and professor of applied chemistry, devised the flash-point test for kerosene, and was the foremost chemical consultant for the petroleum industry at the time. ${ }^{47}$

During the 1880s and 1890s, several pioneer American geologists, notably Israel Charles White and E.B. Andrews, were employed as consultants by oil operators to help in the location of deposits in the Appalachian fields. ${ }^{48}$ White successfully worked out various theories on the accumulation of petroleum and natural gas, and became the first geologist to make a specialty of these minerals. He was professor of geology at the University of West Virginia from 1877 to 1892 and State Geologist from 1897 until his death in 1928. In California, where production had taken from 1876 to 1895 to reach an annual output of one million barrels, but doubled in the next three years, professional petroleum geologists began to be employed in 1897, on the Gulf Coast about 1900, in Mexico in 1909, and in Oklahoma in 1913. ${ }^{49}$

Advances in the use of geology proceeded slowly, however, because of resistance from self-educated practitioners on the oil fields, reflected in such slogans as "oil is where you find it," and "geology never filled an oil tank."50 An observer around 1900 commented:

"The opinion of the average oil operator about geologists is today very much the same as that of the foundryman a generation ago, or the steel producer two generations ago, in regard to chemists. It should...be remembered that 
perhaps 75 percent of the prosperous oil operators began as drill hands and that their limited education does not usually enable them to understand or appreciate geological reports." ${ }^{11}$

According to Williamson et al, much credit must go to the U.S. Geological Survey for its role in bringing about a marked change in the general attitude of oil men toward geologists, by publishing reliable field data and popularizing the anticlinal theory of the structure of oil-bearing strata. While the major elements of the theory had been worked out before 1900, the discovery in 1911 of the rich Cushing pool in Oklahoma dramatically demonstrated the theory that anticlines were favorable places to find oil. In 1914, the Oklahoma Geological Survey published a structure-contour map of the Cushing field clearly indicating that the line separating the oil from the water was parallel to the surface structure contours. For the next fifteen years, most new crude discoveries were based on the surface mapping of anticlines. ${ }^{52}$

\section{Mining Education: Forming an Academic-Industrial Nexus}

Over roughly the same span of time during which the United States ascended to leadership in mineral production, the country also became the foremost location for education in mining engineering and metallurgy. The formation of such mutually-reinforcing linkages between this sector of industry and the educational system was by no means inevitable. To illustrate this point, consider that despite its control of a large part of world mineral production in the sixteenth, seventeenth and eighteenth centuries, Spain was far from the forefront of geological science, metallurgy, or mining technology. Although the Spanish did found twentyfive "universities" in America, those scholastic institutions apparently had little regard for technical education. The case of Britain may be cited as a second instance: Although coal, iron, copper, and lead mining were of growing importance from the latter part of the seventeenth century, it was not until the Exhibition of 1851 in London that the "Government School of Mines and Science Applied to the Arts" was established. The name was changed twice before it became the Royal School of Mines in 1863. Perhaps it was this British heritage that caused Australia, despite the great importance of mining for its economy, to invest very little in advanced mining education in the nineteenth century. ${ }^{53}$ By way of comparison, schools of mining had been established, initially under royal patronage, in Sweden in 1684, in Freiberg, Saxony, in 1765, and in Paris, France, in $1783 .{ }^{54}$ The Bergakademie in Freiberg was the most prestigious institution in the mid-nineteenth century, and Americans enrolled there in increasing numbers between 1845 
and the late 1860s, after which time the numbers declined because of the rise of U.S. schools. ${ }^{55}$

Demands for indigenous training institutions adapted to American conditions began at the time of the mining boom in Michigan, and accelerated in the wake of the California gold rush. In 1847 Abbott Lawrence was moved to give $\$ 50,000$ to Harvard to endow professorships in geology and engineering. His accompanying letter reflected the new appreciation of the value of science to the practical business of mining: "The three great practical branches to which a scientific education is to be applied are: first, engineering; second, mining in its extended sense, including metallurgy; third, the inventions and manufacturing of machinery." Contrary to the founder's intentions, however, the Lawrence school developed into one of pure science following the appointment of Louis Aggasiz as professor of zoology and geology, and Eben Horsford as professor of applied chemistry. ${ }^{56}$

The first successful school of mines in the United States was opened by Columbia College in the City of New York, in 1864. Thomas Egleston, a New Yorker who had returned from the Ecole des Mines in 1860, was the prime mover, agreeing to serve initially without salary as professor of mineralogy and metallurgy, and recruiting two others on the same basis. Twice as many students (24) appeared on the first day as had been expected, which must have been gratifying to the three risk-taking faculty members! During the remainder of the decade a number of institutions followed suit by offering instruction in mining engineering. MIT included a mining course from the time of its founding in 1865. In the same year, the University of Michigan established a degree of Mining Engineering, Yale appointed a professor of mining, and Harvard established a chair in geology, endowed by a donor whose express intention was to make it a nucleus of a new School of Practical Mining and Geology. Lafayette College and Lehigh University, two institutions located near the anthracite districts, also began to provide instruction in mining in 1865 and 1866, respectively. Asa Packer, who gave a half-million dollars and a tract of land to help found Lehigh in 1866, had made his fortune through mining and transporting anthracite. A proposal in 1867 by a Nevada Senator for a National School of Mines was unsuccessful, but many state-supported institutions were founded not long after. Foremost among these was the Colorado School of Mines: established by the territorial legislature in 1870, it was the first state mining school set up as a separate institution, and had commenced instruction by 1873.57

In all more than 20 schools in the country granted degrees in mining during 1860-1890. In 1893, Samuel B. Christy, a professor at the University of California, noted that the United States had more mining students than any country in Europe except Germany. Between 1851 and 1890, the Royal School of Mines in London graduated an average of only seven per year, whereas 
the Columbia School of Mines alone produced an average of more than 15 graduates per year during $1867-1893 .{ }^{58}$ Columbia was far and away the dominant institution in this period. As early as 1871, mining expert John A. Church declared it to be "one of the best schools in the world -more scientific than Freiberg, more practical than Paris." ${ }^{59}$ According to Christy, of the 871 mining graduates in the U.S. up to 1892, 402 were products of Columbia. The continuing flow of trained American mining specialists was reflected in a professional identity and organization that was distinctly national in character. When the British Institution of Mining and Metallurgy held its inaugural meeting in London in 1892, the organizers "found it more than a little irksome to have to acknowledge that in the United States some such organization had been operating successfully for nearly twenty years." The British viewed the American Institute of Mining Engineers (founded in 1871) as "at once a reproach and an example to us." ${ }^{60}$

Enrollment continued to grow from the time of Christy's report, especially at the younger schools that had been opened in the western states. At the University of California, which waited 17 years after its founding in 1868 before appointing a professor of mining and metallurgy, the registration of the mining college increased tenfold between 1893 and 1903 . The mining college, which had constituted four percent of the total university enrollment in 1893, represented eleven percent of total enrollment in 1903. With over 300 students in that year, the school claimed to be "without doubt the largest mining college in the world."61

The late nineteenth century also saw a growing interaction between mining schools and industry, culminating in various efforts to bring together engineering science and practical arts. Professor Henry S. Munroe of the Columbia School organized the "Summer School of Practical Mining," which helped students become familiar with the working conditions they would meet after graduation. Professor Robert H. Richards perfected the "Mining Laboratory," where practical problems in ore-dressing and metallurgy could be worked out by students. ${ }^{62}$ More generally, mining engineers began increasingly to assume managerial and executive roles within large firms, and this expectation came to be reflected in the curricula of the major mining schools. ${ }^{63}$ Herbert Hoover, one of the most successful and surely the most famous mining engineer of this era, strongly favored this trend toward combining executive and technical functions, and viewed it as a distinctively American strength. ${ }^{64}$ The contrast was with the European tradition of training mining engineers to serve as inspectors, and in regulatory positions directing the activities of state mining monopolies. Although resistance to collegetrained men continued to be voiced by self-taught miners and prospectors, the demand for these skills continued to grow. "The fact remains," wrote the Mining and Scientific Press in 1915, "that nearly every successful mining operation of consequence, old or new, is today in the hands of 
experienced technically trained men." 65

The 1900 U.S. Census reported 2908 mining engineers, 6034 surveyors, and 8887 chemists, assayers, and metallurgists. By 1917, a manpower census for military purposes counted 7,500 mining engineers, with an extremely broad range of professional experience and mineral specialties (Table 4). Perhaps even more remarkable is the fact that the same survey found that 2112 of these mining engineers had working experience in foreign countries. Although Canada and Mexico were the two largest of these, the experience was in fact widely dispersed among all of the continents of the world (Table 5). A survey of graduates of the Colorado School of Mines between 1900 and 1940 found that 64 percent of them had worked abroad at some time, 39 percent for several years. ${ }^{66}$ The distinctive knowledge and drive of American mining engineers attracted attention very early, in mining centers around the world. In Australia, for example, most of the large mines were managed by Cornishmen into the 1880s, but these men were untrained in metallurgy and resistant to the use of new technology. A turning point in the industry's history came with the decision in 1886 to recruit highly-paid engineers and metallurgists from the Rocky Mountain states, such as William H. Patton from the Comstock lode, and Herman Schlapp from the grimy smelting towns of Colorado. ${ }^{67}$ Later the trend toward "Americanization" of mining activity was remarked on, with various combinations of resentment and admiration, in such faraway locations as Africa, Sibera, and China. ${ }^{68}$ This evidence of demand for American mining technology and expertise is perhaps the best confirmation that the U.S. had by then achieved a position of leadership that was unique in the world. In this same trend, of course, one may see the forces that came to undermine the American economy's position of dominance in world mineral supples.

\section{The "Ethos of Exploration"}

The rapid rate at which nineteenth century Americans committed themselves to finding and extracting wealth from the soil seems remarkable when compared with the pace of geological activities in other countries. Although domestic coal and iron ore deposits played a significant role in the rise of Britain as an economic power, the British government was slow to encourage resource exploration. According to one estimate, before World War II, when Britain spent $£ 70,000$ annually on its geological survey, the U.S. spent the equivalent of $£ 1$ million. Compared with the American West, the "mining frontier" in the British Empire advanced slowly. As late as 1947, expert staff in British geological services overseas -- in an empire that was then still intact -- totaled fifty-eight. ${ }^{69}$ An illustration of the difference in priorities is provided by the Indian industrialist J. N. Tata to establish a modern steel industry in India during the 1890s. After 
visiting steel plants in Britain and Germany as well as the United States, Tata decided to throw his lot with the Americans. When the American advising team arrived, they immediately set in motion an exhaustive search for iron ore in convenient locations. Within a short time they found one of the richest hematite deposits in the world, at Gurumaishini Hill, which the British imperialists had somehow overlooked. ${ }^{70}$ Sometimes when it comes to exploration, believing is seeing.

A strongly developed American "ethos of exploration" -- something like a national consensus that major mineral discoveries could (still) be made, and that public policies should create and maintain a scientific and technological infrastructure supporting private undertakings for that purpose -- emerged from the congressional and scientific community's debates over the establishment of the Geological Survey. The absence of expectations of new discoveries may be a more potent source of persistent resource underdevelopment than the usual list of reasons suggested: small population, large land size, difficult climate, forbidding landscape, and so forth. Belated development of mineral resources in Australia provides a point of comparison. While it is true that a combination of adverse factors discouraged resource exploitation in Australia, many of these same factors were present in the frontier days of the United States. Certainly the population of Australia has been small for a country of its size, not exceeding 8 million as late as the 1940s. Further, the harsh climate of the large desert areas has discouraged migration from coastal areas. But the American Far West shared many of these conditions: San Francisco had only 450 inhabitants in 1847, and Utah and Arizona are not famous for their gentle climate.

Rather, what seems to have been absent in Australia is the atmosphere of buoyant expectations about major new discoveries. The lack of expectations led to misguided policies and lack of survey effort. In 1938, when Australia had recently begun to export iron ore on a small scale and gave promise of expanding traffic, the government imposed an embargo on all iron ore shipments in an effort to conserve the remaining supply -- one that remained in place for the next twenty-five years. The policy was justified by a report to the Commonwealth in May 1938: "it is certain that if the known supplies of high grade ore are not conserved Australia will in little more than a generation become an importer rather than a producer of iron ore." ${ }^{71}$ As late as 1953, the Economist reported: "...although most surface deposits in Australia have now been discovered and developed, no complete geological survey has been made and it is impossible to say how many minerals lie, as they are said to lie in the Sahara, below the barren surface of the Australian desert."72 When the Australian policy regime was decisively changed in the 1960s, lifting the embargo and offering state encouragement to exploration and construction of new ore terminals, a dramatic series of new discoveries opened up previously unknown deposits, not only of iron 
ore but of copper, nickel, bauxite, uranium, phosphate rock and petroleum. By late 1967, proved reserves of iron ore of over 50 percent metal content were already more than 40 times the level of ten years earlier. ${ }^{73}$

Prior to the 1960s, Australians accepted any number of rationalizations for the absence of important minerals such as petroleum: Oil could not be found south of the equator. Australia's rocks were too old to contain oil. The country had been so thoroughly scoured by prospectors that surely nothing valuable could remain to be found. But this very attitude could lead to lethargic and therefore self-confirming search effort. When a search party from the Weipa mission on the Cape York Peninsula found extensive outbreaks of bauxite in 1955, geologist Harry Evans said to himself: "As the journey down the coast revealed miles of bauxite cliffs, I kept thinking that, if all this is bauxite, then there must be something the matter with it; otherwise it would have been discovered and appreciated long ago." Indeed there was nothing wrong with it: by 1964 Weipa held about one-quarter of the known potential bauxite resources in the world. ${ }^{74}$ The historian of Australian mining concludes: "One consistent lesson in the history of Australian mining is the correlation between intelligent searching and discovery... The halo of romance, of luck and unpredictability, which traditionally surrounds the discovery of a mining field obscured this correlation. ${ }^{75}$

Increasingly the "intelligent searching" came to be performed by corporate organizations, mobilizing teams of highly trained professionals using sophisticated scientific methods. Specialized exploration companies began to appear at the end of the nineteenth century, sometimes affiliated with giant mining enterprises, sometimes with vertically-integrated manufacturing firms whose planning horizons continued to expand over both time and space. When its apex-law disputes were terminated by consolidation after 1906, Anaconda expanded its geolocal work on a district-wide basis, setting the new professional standard for mineral zoning and mapping. One examination made for the Guggenheim Exploration Company of Utah Copper Company property in 1903, required sixteen junior engineers as assistants, involved 3,500 samples, took seven months and more than $\$ 150,000$ to complete. ${ }^{76}$ One must allow, therefore, that part of the American "ethos" included the willingness to allow these huge corporations a largely free rein over the American countryside.

Sooner or later, it was inevitable that these broadening horizons would extend into foreign countries. Convinced that it needed to control a secure supply of bauxite a generation ahead of its immediate requirements, the aluminium company Alcoa invested heavily in bauxite mining and development, first in Arkansas in the early 1900s, then in British Guiana as early as 1916, and in central America in the 1950s. ${ }^{77}$ The Weipa bauxite field in Australia was in fact 
developed in partnership with the Kaiser Alumnium and Chemical Corporation of the United States. As the "ethos of exploration" came more and more to reside in the planning departments of corporations with global horizons, the links between resource discoveries and regional or national development performance became correspondingly weaker. 


\section{Conclusion}

After the Civil War the U.S. became the world's leading mineral producer, dominating the international production league-tables across virtually the entire range of major industrial minerals. Although these developments had roots in the antebellum history of mining on the North American continent, the abruptness of the transition after 1865, the fact that mining had remained so limited an activity throughout the preceding epoch of European settlement, and the simultaneity of the expansion in so many separate branches of the minerals sector, all suggest that it is too simple to say merely that geological good fortune had favored the country with a rich "natural" endowment. Instead, we have argued, the condition of natural resource abundance is one that in general should be viewed as having been "socially constructed" rather than geologically fore-ordained, and the rise of the U.S. minerals economy in this particular era therefore needs to be analyzed as an endogenous phenomenon -- part and parcel of the national economic development process.

Set against the background of expanding domestic and international demands for coal, iron ore, copper, bauxite, petroleum, and many other industrial minerals (and the more erratically growing monetary requirements for silver and gold), our discussion highlights the complex legal, institutional, technological and organizational adaptations that shaped the supplyresponses of individuals and business firms in the U.S. Their combined effects -- in mobilizing resources and knowledge for more systematic exploration, for rationalized, large-scale exploitation of mineral deposits, and for increasingly efficient smelting and refining of the raw materials extracted from the earth -- had created highly elastic supply conditions for American mineral products. This, in turn, facilitated and may even have contributed to inducing the growing mineral resource intensity of U..S. industrial productions and exports during the early decades of the twentieth century. Whereas the substitution of materials mined from the earth for those gathered from the forests traditionally is accorded a place in accounts of the Industrial Revolution of the eighteenth century, and whereas historians of technology have recognized that the same substitutions of minerals for wood were delayed in the American industrial expansion in the first half of the nineteenth century, we believe the significance of the subsequent American minerals development boom has gone largely unrecognized and under-appreciated. Recent reinterpretations of the British Industrial Revolution by economic historians working within the growth accounting framework have tended to downplay even the "supporting actor" roles traditionally assigned to coal and iron. On the other hand, the careful examination of Britain's energy requirements in that era by Wrigley and Thomas, and the emphasis which the work of 
John Harris gives to the minerals sector as the distinctive locus of English industrial skill development, indicate that the revisionists are perhaps missing some important parts of the story. Indeed, our examination of the late nineteenth century American experience suggests that a cross-country and cross-century comparative study of the "social construction of natural resource abundance" would be well worth undertaking.

For many economists, the greater role for primary production and natural resources in pre-twentieth-century economic growth implies that the principle of diminishing returns was then operative to a far greater degree than is the case in the present century. Natural resources still are viewed as the last of the exogenous factors in an economic growth process whose other constituents increasingly have come to be treated as endogenous. ${ }^{78}$ The dependence of industrialization on consumption of exhaustible minerals has been seen, at least from the time of W. S. Jevons' The Coal Question, as exerting a progressively heavier drag on the rate of economic growth -- albeit, one that might be overcome by a quickening of the pace of technological innovation. This analytical association of mineral-intensive development with diminishing returns, and the corresponding disposition to disparage the role of natural resouces in successful industrialization, seem to us the unfortunate legacy of an insufficiently attentive reading of the historical record. In the preceding pages, we not only have called attention to the many respects in which the economically effective mineral resource base was not a "given", not simply a geological endowment, exogenously provided for use in the American economy; we have gone farther, in identifying several strong "positive feedback" mechanisms present in the developmental dynamics of the depletable resource industries, and in noticing significant elements of increasing returns in the processes of minerals discovery, extraction, and utilization.

We have grouped the forces of social construction under three headings: development of an infrastructure of public scientific knowledge; investment in mining education; and the "ethos of exploration," by which term we encompass the broad cultural complex that lay behind the belief in the desirability and feasibility of continuing mineral discoveries, and the accommodating legal and political environments supporting these developments. With minor relabeling, these categories could well be described as the components of sucessful modern-day regime of knowledge-based economic growth. In many respects, the minerals economy was integral to the emerging knowledge-based sectors of the twentieth century U.S. economy.

We also find parallels between the historical experience recounted here and modern instances that have drawn the attention of "new growth theorists" to the role of increasing returns to scale and other sources of positive feedback to the spatial localization of innovation. Our analysis has shown that a variety of factors tended to create geographical clusterings of high 
profit opportunities in minerals development, not simply as a reflection of a comparable spatial concentration in the underlying geological deposits. First, there were knowledge spillovers from one mineral to another. A thorough search of a given territory, made with the objective, say, of locating deposits of gold and silver, simultaneously augmented knowledge about the existence and location therein of copper, lead and zinc deposits. Breakthroughs in the technologies of separating one metal from its ore were readily transferred to other ores, and frequently, in the course of such applications a range of new recoverable byproducts were generated. A second source of increasing returns was lumpiness in physical infrastructure investments. Transportation facilities are a good example: tracks that were laid to service the gold and silver fields also lowered the marginal costs of access to other mineral deposits in adjacent districts. The same principle applied in the case of institutional infrastructures as well, providing a third source. The federal geological surveys, for example, although initiated and institutionalized in the coal-fuel era, had their greatest payoffs in the petroleum discoveries of the twentieth century. Similarly, the institutional linkage among mining firms, mining schools, the USGS, and the American Institute of Mining Engineers is a good example of a technological informationtransmission network, facilitating the accretion and dissemination of useful knowledge from one setting to another within the common geopolitical territory.

Many and perhaps most of these positive feedback mechanisms had their greatest impact within the geopolitical territory known as the United States, at least during the era under examination. Many were geographically defined by their very nature, as in the examples of transportation facilities and mapmaking. Others were largely national in scope for evident historical reasons. The accommodating legal and political setting, for example, was not routinely extendable across national boundaries. It was only to be expected that the graduates of American mining schools would find employment most readily with the regional mining companies who had close relationships with their instructors, and who worked in a relatively familiar geological and business environment. In all of these ways, increasing returns were manifest in mineral resource abundance at the national level, with important consequences for American industrialization and world economic leadership.

More fundamentally, however, the spillovers of knowledge from the American minerals sector proved not to be containable within the nation's borders. The very fact of professionalization, and the linkage of mining education to university departments concerned with general principles as well as specifically useful techniques, made it more likely that the knowledge and skills generated in the American minerals sector would be found useful when transferred to other parts of the world. And, quite plausibly, because American mining eningeers 
were educated and accustomed to meeting the needs of minerals producers over a wider and more varied geological terrain, the knowldge transfers abroad were accomplished more quickly and easily than was the case when the experts involved had been recruited from the craft-based traditions of British mining. Although it was hardly an instantaneous process, these knowledge transfers were rapid enough in the years following World War II to become an important force weakening the links between domestic mineral resources an the performance of America's industry. Today the U.S imports at the margin virtually every one of the major industrial minerals, a state of affairs that hold true for nearly all of the successful industrial nations of the world. Perhaps it is the context and vantage point created by the rapid postwar globalization of the minerals economy that accounts for the otherwise puzzling neglect of this important chapter in American economic history. 


\section{References}

Arthur, W. Brian. "Positive Feedbacks in the Economy," Scientific American, 262 (February 1990): 92-99.

Baykov, Alexander, "The Economic Development of Russia," Economic History Review 7 (December 1954): 137-149.

Blainey, Geoffrey, The Rush That Never Ended: A History of Australian Mining (Carlton, Victoria, 1969; second edition).

Bruce, Robert V. The Launching of Modern American Science. 1846-1876. (Ithaca, 1988).

Cain, Louis P., and Donald G. Paterson. "Biased Technical Change, Scale and Factor Substitution in American Industry, 1850-1919," Journal of Economic Historv 46 (March 1986): 153-164.

Chandler, Alfred D. "Anthracite Coal and the Beginnings of the Industrial Revolution in the United States," Business History Review 46 (Summer 1972): 141-181.

Christy, Samuel B. "Growth of American Mining Schools and Their Relation to the Mining Industry," Transactions of the American Institute of Mining Engineers 23 (1893): 444-465.

Culver, William W., and Cornel J. Reinhart, "Capitalist Dreams: Chile's Response to NineteenthCentury World Copper Competition," Comparative Studies in Society and History (1989): 722744.

De Waal, Enid. "American Technology in South African Gold Mining before 1899," Optima 33 (June 1985): 81-85.

Edelstein, Michael, "Professional Engineers in AustraliaInstitutional Response in a Developing Economy, 1860-1980," Australian Economic History Review 28 (September 1988): 8-32.

Ellison, Joseph. 'The Mineral Land Question in California, 1848-1866," Southwestern Historical Quarterly 30 (1926), reprinted in Vernon Carstensen (ed.), The Public Lands (Madison, 1963). Franklin, Benjamin. "Observations Concerning the Increase of Mankind and the Peopling of Countries," in Jared Sparks (ed.), The Works of Benjamin Franklin( Boston, 1838).

Gates, William B., Michigan Copper and Boston Dollars: An Economic History of the Michigan Copper Industry ( Cambridge, 1951).

Greene, John C., and John G. Burke, The Science of Minerals in the Age of Jefferson. Transactions of the American Philosophical Society, Volume 68, Number 4 (Philadelphia, 1978).

Hallagan, William S., "Share Contracting for California Gold," Explorations in Economic History 15 (April 1978): 196-210.

Harris, John. Essays in Industry and Technology in the Eighteenth Century: England and France. (Hampshire, 1992). 
Harvey, Charles, and Jon Press. "Overseas Investment and the Professional Advance of British Metal Mining Engineers, 1851-1914," Economic History Review 42 (February 1989).

Harvey, Charles, and Jon Press, International Competition and Industrial Change: Essays in the History of Mining and Metallurgy 1800-1950 (London, 1990).

Headrick, Daniel R., The Tentacles of Progress: Technology Transfer in the Age of Imperialism 1850-1940 (New York, 1988).

Hoover, Herbert C., Principles of Mining (New York, 1909).

International Geologic Congress, The Iron-Ore Resources of the World. (Stockholm, 1910).

Leshy, John D. The Mining Law: A Study in Perpetual Motion (Washington, D.C., 1987.

Libecap, Gary D. The Evolution of Private Mineral Rights: Nevada's Comstock (New York, 1978).

Libecap, Gary D. "Economic Variables and the Development of the Law: The Case of Western Mineral Rights," Journal of Economic History 38 (June 1978): 338-362.

Libecap, Gary D., "Government Support of Private Claims to Public Minerals," Business History Review 53 (Autumn 1979): 364-385.

Libecap, Gary D., "Property Rights in Economic History," Explorations in Economic History 23 (July 1986): 227-252.

Libecap, Gary D., Contracting for Property Rights (Cambridge, 1989).

McCurdy, Charles W., "Stephen J. Field and Public Land Development in California, 1850-1866," Law and Society Review 10 (Winter 1976): 235-266.

Manning, Thomas G._ Government in Science -- The U.S. Geological Survey 1867-1894 (Lexington, 1967).

Mayer, Carl J., and George A. Riley, Public Domain, Private Dominion (San Francisco, 1985).

Merrill, George P., The First One Hundred Years of American Geology (New Haven, 1924).

Nash, Gerald D State Government and Economic Development in California (Berkeley, 1964).

Ochs, Kathleen H., "The Rise of American Mining Engineers: A Case Study of the Colorado School of Mines," Technology and Culture 33 (July 1992): 278-301.

Parker, William N. "The Land: Minerals, Water, and Forests," chapter 4 in Lance Davis et al, American Economic Growth (New York, 1972).

Paul, Rodman Wilson, "Colorado as a Pioneer of Science in the Mining West," Mississippi Valley Historical Review 47 (June 1960): 34-50.

Powell, H. Benjamin, Philadelphia's First Fuel Crisis (University Park, 1978).

Read, Thomas Thornton, The Development of Mineral Industry Education in the United States (New York, 1941).

Richter, F.E., "The Copper-Mining Industry in the United States, 1845-1925," Quarterly Journal 
of Economics 41 (February 1927): 236-291.

Rickard, T.A., A History of American Mining ( New York, 1932).

Romer, Paul M., "Increasing Returns and Long-Run Growth," Journal of Political Economy 94 (1986): 1002-1037.

Romer, Paul M., "Endogenous Technological Change," Journal of Political Economy 98 (1990): S71-102.

Rothwell, R.P. "American Mines," Chapter XXVII in Chauncey M. Depew (ed.), One Hundred Years of American Commerce (New York, 1895).

Scheiber, Harry, "Property Law, Expropriation, and Resource Allocation by Government: The United States, 1789-1910," Lournal of Economic History 33 (March 1973): 232-251.

Schmitz, Christopher J., World Non-Ferrous Metal Production and Prices 1700-1976 (London, 1979).

Schmitz, Christopher J. "The Rise of Big Business in the World Copper Industry, 1870-1930," Economic History Review 39 (1986): 392-410.

Shinn, Charles H., Mining Camps: A Study in American Frontier Government (New York, 1948). First published 1885.

Smith, Adam, An Inquiry into the Nature and Causes of the Wealth of Nations (New York, 1937). First published 1776.

Smith, George Otis (ed.)., The Strategy of Minerals (New York, 1919).

Spence, Clark C., Mining Engineers and the American West 1849-1933 (New Haven, 1970).

Swenson, Robert W., "Legal Aspects of Mineral Resources Exploitation," chapter 23 in Paul Gates, Historv of Public Land Law Development (Washington, D.C., 1968).

Temin, Peter, Iron and Steel in Nineteenth Century America (Cambridge, 1964).

Thomas, Brinley. The industrial Revolution and the Atlantic Economy: Selected Essays (London, 1993).

Umbeck, John, "The California Gold Rush: A Study of Emerging Property Rights," Explorations in Economic History 14 (July 1977): 197-226.

Umbeck, John, "Might Makes Rights," Economic Inquiry 19 (January 1981): 38-59.

United Nations, Survey of World Iron-Ore Resources (New York, 1955).

United States Bureau of Mines, "Census of Mining Engineers, Metallurgists, and Chemists," Technical Paper No. 179 (1917).

Van Wagenen, Theo. F., International Mining Law (New York, 1918).

Veatch, A. C. "Growth of American and Australian Mining Law," The Engineering and Mining Journal 89 (April 1910): 716-720. 
Warren, Kenneth, Mineral Resources (Baltimore, 1973).

White, Colin, Russia and America: The Roots of Economic Divergence (London, 1987).

White, Gerald T., "California's Other Mineral," Pacific Historical Review 39 (May 1970): 135-154.

Williamson, Harold F., and Arnold R. Daum, The American Petroleum Industry (Evanston, 1959).

Williamson, Harold F., Ralph Andreano, Arnold R. Daum, Gilbert C. Klose, The American Petroleum Industry: The Age of Energy 1899-1959 (Evanston, 1963).

Wilson, A.J., The Professionals: The Institution of Mining and Metallurgy 1892-1992 (London, 1992).

Wirth, Fremont P. "The Operation of the Land Laws in the Minnesota Iron District," Mississippi Valley Historical Review 13 (1927), reprinted in Vernon Carstensen (ed.), The Public Lands (Madison, 1963).

Wright, James E., The Galena Lead District: Federal Policy and Practice 1824-1847 (Madison, 1966).

Wright, Gavin. "The Origins of American Industrial Success, 1879-1940," American Economic Review 80 (September 1990): 651-668.

Wrigley, E.A., Continuity, Chance and Change (Cambridge, 1988). 


\section{Notes}

1. Wright, "The Origins of American Industrial Success," pp. 655-660. Cain and Paterson, "Biased Technical Change," find a materials-using technological bias in nine of twenty U.S. industries during the same period, including many of the most prominent success stories.

2. Parker, "The Land, Minerals, Water and Forests," p. 96.

3. Smith, The Strategy of Minerals, p. 282.

4. E. A Wrigley, Continuity, Chance and Change; Brinley Thomas, Industrial Revolution.

5. International Geologic Congress, Iron-Ore Resources, p. 4.

6. Warren, Mineral Resources, p. 172.

7. Franklin, Works, pp. 311-320.

8. Smith, Wealth of Nations, p. 531.

9. Ibid., p. 531.

10. Quoted in Rickard, History of American Mining, p. 2.

11. Read, Mineral Industry Education, p. 11.

12. Powell, Philadelphia's First Fuel Crisis, discusses the extensive investments by the Weiss and Cist mining company in land acquisition, transportation and promoting the use of anthracite. Chandler, "Anthracite Coal," identifies the opening of the anthracite fields as the key breakthrough allowing the rise of large-scale, steam-powered factories in America.

13. Harvey and Press, "Overseas Investment," p. 65.

14. Schmitz, World Non-Ferrous Metal Production, pp. 9-17.

15. Yet the editors of a recent compendium of research on the history of mining and metallurgy write: "Most observers -- including some eminent economists -- have inclined to the view that the discovery of workable mineral reserves is largely a matter of chance, and therefore not susceptible to economic analysis... To date, only a few writers have asserted that the discovery of mineral deposits has been economically determined..." (Harvey and Press, International Competition and Industrial Change, p. 2.) The only examples given have to do with the timing of discoveries relative to industrial demands. Nothing in the volume addresses the systematically uneven geographic incidence of mineral discoveries around the world.

16. See the chart in Parker, "The Land," p. 99. 
17. White, Russia and America, pp. 64-68. White relies largely on Baykov, "The Economic Development of Russia," pp. 140-143.

18. Richter, "Copper-Mining Industry," p. 259; Gates, Michigan Copper and Boston Dollars, p. 92; Schmitz, "Rise of Big Business," p. 403; Harvey and Press, "Overseas Investment," p. 72. An account of the contrasting histories of the U.S. and Chilean copper industries may be found in Culver and Rinehart, "Capitalist Dreams."

19. Mayer and Riley, Public Domain, Private Dominion, who deplore the free exercise of profitseeking energies on the public domain, state that U.S. mining law is anomolous among the nations of the world (p. 78). After an exhaustive review of international mining laws in 1918, Van Wagenen concluded that prospecting was nowhere else as free as in the United States (International Mining Law, p. 117.

20. Ibid., p. 287: "Outside of the United States and Alaska the prospector, as so understood, does not exist."

21. Wright, The Galena Lead District; Mayer and Riley, Public Domain, Private Dominion, ch. 2. 22. Swenson, "Legal Aspects of Mineral Resources Exploitation," p. 705.

23. Mexican land and mineral laws were abolished by edict of Colonel Mason, ten days after the signing of the Treaty of Guadalupe Hidalgo in 1848. Although the issues were hotly debated, Congress was unable to agree on any legislation and hence took no action. The new California state legislature also could not agree on substantive legislation, and somewhat ambiguously adopted into law in 1851 "the customs, usages, or regulations established and in force" at each local "bar or diggings." See Ellison, "The Mineral Land Question in California," pp. 77-82.

24. See especially Umbeck, "The California Gold Rush." Umbeck also holds, however, that "ultimately all ownership rights are based on the abilities of individuals, or groups of individuals, to forcefully maintain exclusivity." Umbeck, "Might Makes Rights," p. 39. He points out that the signs posting claims often displayed threatening warnings to maintain a safe distance.

25. McCurdy, "Stephen J. Field and Public Land Law Development in California," p. 240.

26. Quoted in McCurdy, "Stephen J. Field," p. 245. This discussion generally follows McCurdy, especially pp. 237-245.

27. This assumption is clear in the theoretical section of Umbeck, "The California Gold Rush," pp. 198-202. See also Libecap, "Economic Variables;" The Evolution of Private Mineral Rights; and "Government Support of Private Claims to Public Minerals," p. 367. Hallagan, "Share Contracting for California Gold," documents the use of share-lease arrangements for quartz and drift claims, 
where yields were uncertain and claim-specific investments required. Such contracts were indeed adaptations to the uncertainties of mining. But they came into play only after the creation of transferable claims through the procedures of the mining laws, which in this case had resulted in a glut of unattractive "prospects" in the secondary resale market. As Hallagan brings out, the leases were subject to the well-known incentive and monitoring shortcomings of share arrangements.

28. Van Wagenen, International Mining Law, pp. 102-103. The following statement by Van Wagenen may also be of interest: "That there are yet vast undiscovered mineral resources in Europe is confidently believed by those who are best acquainted with its general geology" (p. 213).

29. Mayer and Riley, Public Domain, Private Dominion, pp. 114-117.

30. Wirth, "The Operation of the Land Laws in the Minnesota Iron District."

31. La Croix, "Property Rights and Institutional Change during the Australian Gold Rush," pp. 223-225. La Croix points out that the local mining authorities in New South Wales, having won a high degree of authority in the miners' rebellion of 1854, subsequently resisted the introduction of capital intensive methods by large mining companies (p. 222).

32. Veatch, "Growth of American and Australian Mining Law," p. 717.

33. Rickard, History of American Mining, pp. 359-361; Spence, Mining Engineers and the American West, pp. 222-226. Spence points out that giving paid expert legal testimony in apex cases was one of the most lucrative pursuits for graduates of American mining schools (pp. 199201). La Croix notes that gold miners in Ballaret (in Victoria) adopted a very different but equally defensible "frontage" system of circular allotments, each miner with a given length of lead. This too was an attempt to balance the incentive to invest against the demands of equity and the difficulties of enforcement (La Croix, "Property Rights and Institutional Change," p. 219).

34. A series of articles developing these themes is usefully summarized in Libecap, "Property Rights in Economic History," pp. 242-247, and in Libecap, Contracting for Property Rights, chapter 6. A synopsis of the legal history of the "rule of capture" may be found in Williamson and Daum, The American Petroleum Industry, pp. 758-766.

35. The examples are from Nevada, as reported in Libecap, "Government Support of Private Claims," pp. 374-375. Libecap writes: "The transition of Comstock mining from pick and shovel to factory operations required continued legislative response" (ibid, p. 373, emphasis added). The theme of the "developmental state" in American federal history parallels such interpretations as 
Scheiber, "Property Law, Expropriation, and Resource Allocation by Government," and Nash, State Government and Economic Development. The contrast with the revenue-oriented posture of the Chilean government is striking (Culver and Reinhart, "Capitalist Dreams").

36. Bruce, The Launching of Modern American Science, p. 139.

37. Bruce, Launching of Modern American Science, pp. 166-167.

38. Bruce, Launching of Modern American Science, pp. 139-140. On the development of the Michigan copper fields, see Gates, Michigan Copper and Boston Dollars.

39. This account is adapted from that of Carroll Pursell, in G. H Daniels (ed.), Nineteenth Century American Science (Evanston , Illinois, 1972).

40. Manning, Government in Science, pp. 2-3, 31-32; Bruce, Launching of Modern American Science, pp. 203-205.

41. Quoted in Manning, Government in Science, pp. 10-11.

42. Spence, Mining Engineers and the American West, pp. 113-114.

43. Manning, Government in Science, pp. 4-14, 216; Rodman Wilson Paul, "Colorado as a Pioneer of Science in the Mining West."

44. Spence, Mining Engineers and the American West, p. 60. Spence quotes a 1912 editorial in the Mining and Scientific Press as follows: "Good men go but others come, and the Geological Syrvey is fast becoming, as an incident to its main work, a great graduate school of instruction. To call the role of ex-employees is almost to list the successful men of the mining profession. So long as the spirit remains right and the work is honest and thorough, the Survey can continue, like a university, to send its men out into other branches of professional service."

45. Thomas Thornton Read, The Development of Mineral Industry Education in the United States, p. 189.

46. Williamson et al, The American Petroleum Industry: The Age of Energy, p. 29.

47. Read, Development of Mineral Industry Education, p. 191.

48. Williamson et al, Age of Energy, p. 441.

49. Read, Development of Mineral Industry Education, pp. 190-191.

50. White, "California's Other Mineral," p. 146.

51. Quoted by Williamson et al, Age of Energy, p. 441.

52. Williamson et al, Age of Energy, pp. 45-46. 
53. Edelstein, "Professional Engineers in Australia," pp. 22, 29.

54. Greene and Burke, The Science of Minerals in the Age of Jefferson, pp. 6-7.

55. Read, Development of Mineral Industry Education, pp. 13, 27-28; Spence, Mining Engineers and the American West, pp. 9, 25.

56. Read, Development of Mineral Industry Education, p. 23. Read remarks that "[a] less congenial atmosphere for the development of applied science than existed in the Harvard of 1847 is not easily imagined..."

57. This summary draws on Read, Development of Mineral Industry Education, pp. 44-98.

58. Christy, "Growth of American Mining Schools," p. 445.

59. Quoted in Spence, Mining Engineers and the American West, p. 38.

60. Wilson, The Professionals, pp. 8-9. Wilson notes that at that time, the AIME had a membership of 2000, while Britain "would be hard pressed to muster more than a couple of hundred" (p. 21). The IMM covered only metal-mining, the coal-mine engineers having established their own organization in 1889.

61. Read, Development of Mineral Industry Education, p. 84.

62. Christy, "Growth of American Mining Schools," p. 461.

63. Ochs, "The Rise of American Mining Engineers."

64. Hoover Principles of Mining, pp. 185-191. A survey of graduates of the mining curriculum at Harvard's Lawrence Scientific School for 1897-1905 found that fully one-third were engaged as managers or superintendents at the time of the poll (Spence, Mining Engineers and the American West, p. 139).

65. Quoted in Spence, Mining Engineers and the American West, p. 142.

66. U.S. Bureau of Mines, "Census of Mining Engineers," pp. 8-9; Ochs, "Rise of American Mining Engineers," pp. 288-298.

67. Blainey, The Rush that Never Ended, pp. 154, 252

68. Spence, Mining Engineers and the American West, chapter 9. Because hard quartz rock mining requited techniques "unknown to most British mining engineers," Americans were offered "princely salaries" to come to South Africa in the 1880s and 1890s. An American served as the State Mining Engineer in the Transvaal in 1888; another was the first president of the South African Association of Engineers and Architects; and a third was one of the first presidents of the 
Chemical and Metallurgical Society formed in 1894. See Enid de Waal, "American Technology in South African Gold Mining," pp. 81-85.

69. Warren, Mineral Resources, p. 22.

70. This account is drawn from Daniel R. Headrick, The Tentacles of Progress, pp. 285-291.

71. Quoted in Blainey, The Rush that Never Ended, p. 346.

72. Economist 7 March 1953, cited in Warren, Mineral Resources, p. 17.

73. Warren, Mineral Resources, p. 215.

74. This account is from Blainey, The Rush that Never Ended, pp. 340-341.

75. Ibid, p. 347.

76. Spence, Mining Engineers and the American West, pp. 91, 229.

77. George David Smith, From Monopoly to Competition: The Transformations of Alcoa, 18881986 (Cambridge, 1988), pp. 97, 98, 142, 321.

78. See, e.g., Romer, "Increasing Returns and Long Run Growth," and "Endogenous Technological Change." Brian Arthur, in "Positive Feedbacks in the Economy," argues explicitly that diminishing returns probably predominated in nineteenth century economies, because of the greater role for scarce physical resources, as contrasted with knowledge-based resources. 
TABLE 1. US SHARE OF WORLD TOTALS

(percent)

$\begin{array}{cccc}1913 & 1989 & 1989 \text { Reserves plus } & 1989 \text { Reserve Base plus } \\ \underline{\text { Output }} & \underline{\text { Reserves }} & \underline{\text { Cumulative 1913-1989 }} & \text { Cumulative 1913-1989 }\end{array}$

$\begin{array}{lllrr}\text { Petroleum } & 65 & 2.96 & 19.77 & \\ \text { Copper } & 56 & 16.40 & 19.94 & 18.50 \\ \text { Phosphate } & 43 & 9.80 & 36.30 & 15.43 \\ \text { Coal } & 39 & 23.00 & 23.32 & \\ \text { Bauxite } & 37 & 0.17 & 0.52 & 0.50 \\ \text { Zinc } & 37 & 13.89 & 13.96 & 15.58 \\ \text { Iron Ore } & 36 & 10.46 & 11.56 & 7.39 \\ \text { Lead } & 34 & 15.70 & 18.13 & 18.79 \\ \text { Gold } & 20 & 11.50 & 8.61 & 8.43\end{array}$

SOURCES: Minerals Yearbook; The Mineral Industry Its

Statistics, Technology and Trade; American Petroleum Institute,

Basic Petroleum Data Book, Volume X (September 1990);

National Coal Association, International Coal; COE/EIA, Annual

Prospects for World Coal Trade 1991. 
TABLE 2. EUROPEAN SHARE OF WORLD TOTALS

(percent)

$\begin{array}{cccc}1913 & 1989 & 1989 \text { Reserves plus } & \text { 1989 Reserve Base plus } \\ \underline{\text { Output }} & \underline{\text { Reserves }} & \text { Cumulative 1913-1989 } & \text { Cumulative 1913-1989 }\end{array}$

$\begin{array}{lclrr}\text { Petroleum } & 4.70 & 4.83(\mathrm{a}) & 9.02 & \\ \text { Copper } & 10.30 & 6.80 & 7.04 & 4.50 \\ \text { Phosphate } & 8.60 & 0.20 & 0.42 & 0.31 \\ \text { Coal } & 55.00 & 13.00 & 16.82 & \\ \text { Bauxite } & 60.00 & 6.10 & 7.09 & 17.09 \\ \text { Zinc } & 67.90 & 18.10 & 20.40 & 17.09 \\ \text { Iron Ore } & 58.20 & 3.44 & 6.28 & 5.38 \\ \text { Lead } & 48.50 & 12.90 & 18.11 & 16.31 \\ \text { Gold } & 1.00 & 6.10 & 2.62 & 2.56\end{array}$

a: Western Europe plus Communist Nations except USSR

SOURCES: Same as Table 1. European countries are Albania,

Austria, Belgium, Bulgaria, Czechoslovakia, Denmark, Finland,

France, Germany, Greece, Greenland, Hungary, Ireland, Italy,

Luxembourg, The Netherlands, Norway, Poland, Portugal,

Romania, Spain, Sweden, Switzerland, United Kingdom, and

Yugoslavia. 
TABLE 3. USSR SHARE OF WORLD TOTALS

(percent)

$\begin{array}{cccc}1913 & 1989 & 1989 \text { Reserves plus } & 1989 \text { Reserve Base plus } \\ \text { Output } & \underline{\text { Reserves }} & \text { Cumulative 1913-1989 } & \text { Cumulative 1913-1989 }\end{array}$

$\begin{array}{lrlrr}\text { Petroleum } & 29.0 & 6.44 & 18.02 & \\ \text { Copper } & 3.4 & 0.70 & 4.72 & 8.79 \\ \text { Phosphate } & 0.0 & 10.60 & 19.08 & 5.44 \\ \text { Coal } & 2.5 & 22.00 & 21.04 & \\ \text { Bauxite } & 0.0 & 1.40 & 1.92 & 1.71 \\ \text { Zinc } & 0.0 & 6.90 & 9.20 & 7.56 \\ \text { Iron Ore } & 5.7 & 39.07 & 36.41 & 24.39 \\ \text { Lead } & 0.1 & 14.20 & 10.98 & 10.83 \\ \text { Gold } & 5.4 & 1.40 & 10.99 & 10.81\end{array}$

SOURCES: Same as Table 1. 
TABLE 4. EXPERIENCE OF US MINING ENGINEERS, 1917

$\begin{array}{lr}\text { Metallurgy (all kinds) } & 2,920\end{array}$

Development Work 2,325

Surveying, mine or topographic $\quad 1,935$

$\begin{array}{ll}\text { Construction (building) } & 1,770\end{array}$

Erection of Machinery $\quad 1,050$

$\begin{array}{ll}\text { Ore Concentration } & 1,038\end{array}$

Designing and drafting $\quad 945$

Explosives (mine and quarry) 863

Prospecting (boring machines) 840

$\begin{array}{ll}\text { Construction (machinery) } & 735\end{array}$

$\begin{array}{ll}\text { Assaying } & 718\end{array}$

Drainage and pumping $\quad 563$

Steam-shovel mining $\quad 330$

$\begin{array}{ll}\text { Hydraulic mining } & 173\end{array}$

$\begin{array}{ll}\text { Quarrying } & 165\end{array}$

$\begin{array}{ll}\text { Dredging } & 115\end{array}$

$\begin{array}{ll}\text { Dike and levee construction } & 98\end{array}$

Tunnel and shaft work $\quad 83$

$\begin{array}{ll}\text { Miscellaneous* } & 1,615\end{array}$

* Includes 467 consulting mining engineers; 312 geologists; 121 professors of mining, metallurgy, and geology.

SOURCE: Albert H. Fay, "Census of Mining Engineers, Metallurgists, and Chemists," United States Bureau of Mines Technical Paper No. 179 (1917), pp. 8-9. 
TABLE 5. EXPERIENCE IN FOREIGN COUNTRIES OF US MINING ENGINEERS AND CHEMISTS, 1917

Mining Engineers

Africa

Australasia

Austria-Hungary

Canada

Central America

Cuba

Europe

Belgium

Denmark

France

Great Britain

Germany

Holland

Italy

Norway-Sweden

Russia

Spain

Switzerland

Others

Not Specified

Far East

Greenland

India

Mexico

Newfoundland

South America

West Indies
74

46

7

384

74

68

6

1

23

116

61

2

5

19

25

7

8

22

101

105

3

11

679

7

241

17
Chemists

13

19

24

203

15

60

6

19

38

117

231

10

11

21

30

5

18

10

171

80

117

34

32

SOURCE: Albert H. Fay, "Census of Mining Engineers, Metallurgists and Chemists," United States Bureau of Mines Technical Paper No. 179 (1917), p. 11. 